\title{
The Emerging Filmmaking Methodologies in Virtual Space
}

\author{
Sanal Alemde Yeni Oluşmakta Olan Film Yapımı Yöntemleri
}

\begin{abstract}
Jodi NELSON*
Abstract: With the pervasiveness of the Internet pulsing through our everyday lives; one has to wonder what the word 'privacy' entails. As filmmakers, what benefits or repercussions do we face with so much free access to 'private' information out on the web for the world to see? And how can we justify a 'truth' when there is no governing body to say so? While trying to find answers to these questions, I narrate my experiences as a filmmaker who makes use of participatory filmmaking methods through what might be called a case study. I articulate that the reality of the new entrepreneurial filmmaker is not only making just a film project, but rather building a community of like-minded people who support a film project by participating in its production and delivery.
\end{abstract}

Keywords: Social media, film making, digital technology, documentary film, online communities, ethics

Özet: İnternetin günlük yaşamımızda edindiği geniş yeri düşündüğümüzde “gizlilik” ilkesinin ne anlama geldiğini de yeniden düşünür olduk. Dünyanın gözlerinin önüne serilmiş ve erişime açık bulunan bu kadar çok sayıda özel hayatla ilgili bilgi ve görüntülerin biz film yapımcılarına getirdiği zorluk ve yararların neler olduğunu da düşünür olduk. Buna ek olarak, "gerçek" dediğimiz şeyi yargılayacak bir otorite yokken onu nasıl algılayabiliriz? Bu sorulara yanıt ararken katılımcı film yapma yöntemleriyle film yaptığım süreçlerde yaşadığım deneyimleri bir vaka çalışması şeklinde aktarmaktayım. Özellikle altını çizdiğim husus yeni girişimci filmciliğin gerçekliği bir film projesini gerçekleştirmekten çok o filmin hazırlanma sürecine katılan ve bir topluluk oluşturan benzer görüşlerdeki insanları bir araya getirmek etrafında şekillenmektedir.

Anahtar sözcükler: Toplumsal medya, film yapımı, dijital teknoloji, belgesel film, sanal topluluk, etik

Every time a film is shot, privacy is violated. (Jean Rouch, 1975 [2003])

With the pervasiveness of the Internet pulsing through our everyday lives; one has to wonder what the word 'privacy' even means anymore. As filmmakers, what benefits or repercussions do we face with so much free access to 'private' information out on the web for the world to see? And how can we justify a 'truth' when there is no governing body to say so? Take Wikipedia for example, which has replaced the use of the Encyclopedia Brittanica, as an authoritative source of information and resources used to verify the 'truth'; which can now be changed intermittently, at will by virtual strangers from anywhere around the world.

This change reminds us that 'in late capitalism, the promise of access to the private is a currency, the trade in which is central to all media forms, from YouTube to Heat magazine to docu-soap' (Rothwell, 2008, 155). With the new paradigm shifts in the film industry, cheap digital technology and the democratization of the filmmaking process, filmmakers now can

\footnotetext{
*Filmmaker and Founder of Hip Chik Productions, Jn89@sussex.ac.uk
} 
connect to an 'expert' global, niche audience with more immediacy through the Internet; engaging virtual communities, utilizing crowd funding support and fan-building initiatives through a variety of social media landscapes.

My own work has revolved around two kinds of practice; the first, a traditional methodology invented by the Hollywood studios, which, from a small independent filmmaker's standpoint proved futile at best. With little to no resources to pull off a production like the big studios do, with their huge studio budgets, political backing, global media support and accounting practices, it seems absolutely ridiculous at this time to pursue independent film production in this manner. The second practice is participatory filmmaking in which my role is as the filmmaker. This method enables others to articulate their experiences through my artistic vision. Through this process, they have just as much (or as little) control as the filmmaker. Although, ultimately control rests in the hands of the filmmaker, as in the post-production processes it is the filmmaker who has the last word.

This is the production methodology which I want to discuss here, as it provides a rich environment for research, practice and debate amongst scholars and the filmmaking community. 'What defines the documentary genre is also at the root of its limitations...here, I shall call for a different perspective on the documentary form: not with a view to discussing what documentary is, but to make some suggestions as the what it could be' (Knudsen, 2008, 109).

In creating the film project and case study entitled: 'Single Girl in a Virtual World: What does a $21^{\text {st }}$ Century Feminist Look Like?' (SGVW), my practice aims to engage multiple social media communities such as; Facebook, Twitter, MySpace, Wordpress, YouTube, Kickstarter and IndieGoGo and ask people to participate in the film project itself with a sense of a creative input. During production, I asked the communities to read the film site's blog, watch its podcasts, comment on the news feed and follow me on Twitter. These efforts are the practicalities necessary for them to participate in the film project itself - either creatively, financially or both. The film's goal, besides the research practice, is seeking to create a passionate discourse amongst fellow feminist activists and social media users in this virtual environment and to create and build a community of like-minded individuals, who collectively enable the film project to become reality.

The project's content has begun to emerge and appears in its raw shape as a video diary of sorts, with participants weighing in on the topic of the week, freely giving their insights, thoughts and feedback through multiple social networks - either in video, text or both. For the filmmaker, this serves as a rich valley of resources that can be integrated in the film's narrative. However, when attempting to construct a narrative thread by gathering content in this way, there are many potential problems. 'Recording a video diary, if you don't want it to become public, is a risk; perhaps more so than a written diary, because the medium of video implies a mass audience' (Rothwell, 2008, 154).

One of the exciting things about these new possibilities for filmmakers and audiences alike, despite the potential ethical pitfalls, is the creative flow of information, access to resources and sharing of content. Independent filmmakers who are limited in budget, time and production technologies can gain a tremendous amount of quality production value by sourcing content in this way.

There are many ethical issues to consider and trust has to be built in creating in this way. I have found that most people in the virtual communities are there by choice. Either they were 'friended' by me, or came of their own free-will through word of mouth, or through connections from their own friend's 'like' pages. However they came to the community, the goal is to keep them there, involve them in the production efforts and keep them just as excited as you are about the project. And to do that, there must be a transparency between the creator and the fan- 
base participating in the project itself. This covers a multitude of scenarios such as; copyright issues, ethical boundaries, life-rights, video-audio rights and original content ownership. By not going overboard with legal paperwork or FBI warning statement placards across every single webpage; simply asking for their permission seems to be fair enough for their participation. As 'key to the success of that relationship is that it demands a responsibility for the consequences of the filmmaking that go beyond the film itself' (Rothwell, 2008, 155).

When I started this case study, there were of course fears of infringement upon my creative ideas, sharing of content virally amongst the members pervasive throughout the communities in which I fed them the film process. Ultimately, at the base level, I had an overall fear of intellectual property theft; which stemmed from my traditional, Hollywood studio practice experience. Delightfully, once I began my practice in this participatory way, I could begin to see there were actually many benefits in it being 'stolen' and shared virally. The more I blogged and podcasted 'calls-to-action' the more activity my social networks would see, more members would sign up for my news feed, follow me on Twitter, 'Like' my Facebook page, and read my Wordpress blog. Then of course, the whole idea of this process was that once they were fans within my social networks, they would participate and share content which I could then use freely in my film. 'Rather than oppose this "illegal activity" we welcomed the pirating and began distribution directly to the pirates at production cost value' (Blagrove, Jr., 2008, 176).

What I have discovered through this new practice, is the democratization of the filmmaking process and how these new delivery methods are changing the face of the current and future film industry-financially, socially, communally, environmentally, globally, and artistically. And the reality is that the artist who does not embrace such tools and methods of filmmaking, will be left behind. Traditional filmmaking methodologies are giving way to these new mediums as access to 'recycled content' (or according to Birchall 'open source stock clips'), on sites like YouTube and other video rich sites, become accessible 24/7. Textural content, through newsfeeds, blogs and tweets on social media sites such as, Facebook and Twitter have also become a viable source of user-generated material that filmmakers can utilize in their story making process.

Embracing these tools, I have gained the value of peer reviews (as simple as the 'like' button), reached global niche audiences, who would otherwise be unavailable to me within traditional production logistics, and certainly beyond my budget range. These 'fans' are rich with stories and contributions, readily available resources, providing UGC, crowd funding opportunities and have become willing participants; allowing me to create art that is viable, relevant and most of all -cheap, free and viral.

"The on-going conversation with your audience can be a source of inspiration, motivation and ideas. It's this powerful new link with the audience that the old power players don't understand" (Kirsner, 2009, 4). I can no longer imagine going back to a traditional filmmaking practice hoping to make a modest living, or even attempt to have a sustainable career by playing by the old rules of the studio production and delivery system. The windows of financing and distribution are just to complex, too expensive and have too long a cycle to have any hope of quick returns on investments or to gain access to huge marketing budgets for global exposure of film product. In making films in this way, I have gained access to valuable resources and ideas that have built in community support. That type of support equals sustainability, a solid fanbase, and a growing brand.

By empowering ordinary people to speak as experts, they question the basic assumption of dominant ideology, that only those already in power, those who have a stake in defending the status quo, are entitled to speak as if they know something (Juhasz, 2008, 304). It is with this notion, through my research and practice that is measuring how social media, digital technology, alternative production methodologies and various new delivery strategies are providing 
information on the impact of the film's message and its creative process. Does this mean the film is suitable for a theatrical release? The distribution plan certainly goes into the preproduction stages, as with any production. However, for a small, independent artist with no studio backing and a 'day job' to support their 'art habit', this creative participatory practice is a groundbreaking epiphany. 'That's the billion dollar question... what makes a project theatrical, compared to what makes a project just a very good TV documentary. And there's no hard and fast rules. There's a lot of instinct I think that comes into it' (de Jong, \& Austin, 2008, 162).

Setting out on this journey, I had to certainly question if though utilizing social media and cheap digital technology tools, how does it bring the experience between filmmaker and audience together with more immediacy and personal impact? Ultimately, I want to showcase the film; most likely through an online delivery system, but I also want to ensure high production values for possible up-selling through TV, Cable and VOD distribution windows.

My practice experience shows that audience participation does, in fact, inherently impact both the audience and the filmmaker by creating art in this way, through working in this virtual environment. Instead of outsourcing functionalities to other resources in a traditional sense, I had to become an all-encompassing expert. My practice in essence was now creating, in an effort to make art in a truly fundamental and independent way -an open- source, transparent, participatory environment, whereby the audience subjectively became the 'expert'. Then panic set in. Who is in control? Who is the 'auteur' with the vision? What happens if the film's narrative thread goes off-track? Who are the performers and what ethical considerations are at stake?

How can I draw an audience into the reality of the situations being dramatized, 'to authenticate the fictionalization?' ... what are we to make of films where real people apparently 'play themselves' (or variations on themselves), or hybrids where a combination of actors and non-actors improvise in a documentary-like scenario?' (Ward, 2008, 192). It is my job to ensure that the participatory environment also abides by the community rules of transparency, honesty and attributes of authentic form. Otherwise, not seeing these participants in person; looking them in the eye -how am I to know what is factual or fictitious? There are definitely considerations to be made and judgements compromised, all in the name of getting participants for 'free'. 'Notions of performance in documentary are therefore potentially controversial accusations of people 'not being themselves' or 'playacting' are rife, and are deemed to be a central problematic for a film's documentary status or credentials' (Ward, 2008, 192).

A greater embrace of innovation and experimentation in this methodo is needed in leveraging these projects with the ability to fail without showing loss of value. Carefully and creatively being able to 'direct' your subjects in a virtual space without a false pretense, or overcoming a relative disconnect that can be overlooked when physically in the same space should be considered. Technological knowledge and new creative approaches to build communities and better business models for filmmakers and artists alike - are needed. Certainly, this can achieve a quality film status with inherent value-or at the very least to satisfy creative inspirations without being beholden to financiers, distributors or other legal entities who hold creative projects like a dangling carrot.

'Filmmakers don't own their audiences yet (and few even attempt to). What will happen when agents start to cut deals for their clients who have 1 million engaged fans, people who will pre-order their content, promote it passionately, and deliver more of their friends? There is a shift in the balance of power about to happen, and those that have prepared for it, amassed their followings, will be able to change the conversation significantly' (Hope, 2010). By engaging in filmmaking practices in these fundamental ways, a shift of power away from the larger powers of the studios, and back into the hands of the creative filmmakers and their loyal fans should be embraced, not feared. A process of creative flow, execution and community outreach is a necessary 
part of this practice.

'The question for makers, consumers and scholars of moving images are what distinguishes documentary online from documentary made for other channels, and whether the Internet has any distinct, useful or unique characteristics that offer documentary anything more than just another means of distribution' (Birchall, 2008, 279). By making a film in this way new ways of seeing had to be identified; to break me of the traditional molds I had been taught in school and read in industry magazines and books. A profound new shift in mindset was needed to set off on a new course of practice; even though I was unsure of its outcomes. Differences in workflow patterns, means of gathering content, and creation within a new meaning of high production value considerations and compromises and technical limitations would stretch my limits as to what is possible. Also in making a film in an online, participatory environment, I had to figure out how I would amass a collective group of individuals who would, a) be interested in the film project itself, b) like me and my idea, and c) actually have something to contribute that would provide the film with engaging, dramatic, fantastical, heightened content. That's a tall order when staring at a blank Facebook page.

There were several characteristics identified within the area of its preparation in order to successfully launch the project. I had to make it clear to me first, how this would work and fit within a traditional production, business and marketing plan that I had done many times before, without becoming attached to a particular outcome. In this case, I was 'selling' my film to unknowns, virtual people in a global environment; not in front of Hollywood investors, or even fringe angel investors. That world I knew. This was a terrifying reality because these were going to be the audiences who would ultimately determine the fate of the film, and of my continuing as a sustainable filmmaker.

'First, in organizing geographically diverse individuals around a common
interest in watching or making documentaries, there are new forms of
community; second, new means of creation and distribution...to seek to
change people's minds or reinforce a viewpoint; third, we have increased
access to 'dirty reality' in the form of footage of current events and
violent conflict; and fourth, video diaries and other moving images give
us an increased range of intimate access to the lives of other people'
(Birchall, 2008, 179).

It is in this context, greatly to my relief, that I was able to obtain thousands of entries, news feed comments, tweets, sharing of videos and UGC from YouTube and other rich video sites by community members. Skype interviews with members of my community, who wanted to speak one-on-one for a 'sit down' interview also became a relevant source of production activity. During this process, I discovered that because I was developing a rich social network, people I knew in my personal social circles; friends, family, co-workers, business associates, etc. suddenly became keenly aware of the project I was making and were eager, or at least willing when pressed, to participate in the project.

UGC has been the most pervasive provider of content, shared and streamed by my community members so others can comment, share and watch within the framework of the film's websites. Operating on the edge of intellectual property legislation, even though the content is 'free' doesn't mean necessarily it can be utilized in the context of your documentary. 'Documentaries that rely heavily on such footage usually have that footage cleared for broadcast only, making redistribution and reissue difficult' (Birchall, 2008, 280) .

However, UGC can and should be utilized by filmmakers without having to toe the line when it comes to following the rules of an out-dated traditional industry model. 'By contrast, the easy availability of material to work with online is matched by the ease of remixing and 
redistributing' (Birchall, 2008, 280). This aids the independent filmmaker who need opensource, archival clips in order to create a film narrative. This rings especially true when making a film where access cannot be acquired by other such means and/or fit into sub-genres that don't guarantee distribution, such as art films, documentaries and films with controversial subject matter. Creating films in this new methodology, allows a greater freedom, and perhaps a more personal satisfaction in the developing relationship between filmmaker and fans that can't be sustained in a traditional filmmaking-distribution methodology. Not to mentioned reversing the suppression of creative voices by government, lack of funding initiatives or opposition groups. I have been keen to use only the clips I will need and for others, such as video diary content, obtained the permission of the authors to use in the film as well as any promotional efforts utilized in the film's distribution strategy.

It's important to note, that just because technology is cheap, social media pervasive and artistic democracy entering the creative fold, doesn't mean the value of the art or the filmmaker behind its creation should be valued any less. There are many ways to tell a story through transmedia; via gaming, web series, podcasts, and mobile video, as well as texturally through blogs, newsfeeds and tweets. As I stated earlier, I have learned how to be multi-faceted or get left behind. I had to learn a new way to communicate -and often- with my growing online community, who is interested in what I have to say, as well as participate in my creative projects, which, in turn provides its own creative outlet and source of inspiration. 'People made information about themselves available on the Internet in such a way that theoretically anyone could see it, but in practice few did' (Birchall, 2008, 281).

The reality of the new entrepreneurial filmmaker is not only making just a film project, but rather building a community of like-minded people who want to support a film project and future projects - in essence building a sustainable brand. This takes an inordinate amount of time, effort, management and technical trouble-shooting. Not to mention, these technological requirements, necessary to connect all of these networks in a functional and significant way which once they are set up and put in motion, should self-perpetuate. Technology, which can either take away or enhance the traditional filmmaking process, has nevertheless proven itself successful in both the short and long term in this methodology of creation.

During my practice, the benefits in making art in this way far exceed the amount of time and effort it takes to build an online brand and identity. Other filmmakers too, are building sites with the intention of creating a sustainable business model, as well as attracting a built-in fan base that can't be bought with traditional advertising and press campaigns by the larger studios. And they are no longer waiting to be 'discovered' at film festivals or hawking their wares to move to Hollywood. Films are now being made everywhere and there are audiences out there who are looking for them. Audiences, however, are fickle, and entrepreneurial filmmakers have a distinct advantage over the big guys by creating art that is meaningful and creatively autonomous, while building a loyal fan base, which will enable the artist to self-sustain. But, this is a strategic, outof-the-box practice.

This practice has provided my case study with ongoing content (provided by the fans), as well as intimate, direct accessibility to fans and members of the virtual communities. This in turn, provides a valuable source of feedback during the production process. 'The elements that we are used to seeing in documentary films as a mode of representation: talking heads, archive footage and verite' are being reconfigured into new, often fractured and fragmentary forms, mostly by amateurs. The kinds of documentary we find on the Internet follow forms that the Internet has established such as brevity, community, seriality and personal connectedness as much as they follow forms established in the field of documentary filmmaking itself' (Birchall, 2008, 282). 
Further research warranted certain questions, since the methodology itself is created in a new way. Does the 'audience' (virtual community members/fans/friends) participating in the early stages of a creation raise expectations for the audience? What about for the filmmaker? Does it impact upon the artist's methodology of creation itself?

In my experience, participation between audience and filmmaker enables each to develop a relationship that goes deeper than merely from a consumer or isolated artist's point of view. It becomes a two-way process, although as the filmmaker in this case, being positioned as the auteur and the creator of the project, driving the subject matter, its pacing and criteria provided an overall control and direction for the project. It is important to note, that its subject or method itself wasn't diminished in value, nor did it have the perception of being an amateur product. In fact, it's been the opposite, which emphasized stronger value for both the filmmaker and the project being created with the audience. The process has allowed a more authentic, accessible and transparent relationship to develop amongst the community, which makes the film's subject, and experience, more tangible.

Does the filmmaker have more or less of a perceived value in the marketplace among industry peers and audiences in this emerging participatory trend? Specifically, is the artist or the work created 'demystified' in this sense within open-source accessibility?

Having the film aimed specifically towards a key, niche audience, they are keen to be involved and stay invested in the filmmaker for future projects and for the long haul. This depends solely upon the film project itself, for once the filmmaker is successful with one product and moves onto another, you risk losing your audience over a change in content or through lack of interest. Therefore, the use of transmedia content lets the audience know there's something in it for them, besides just the co-creation element.

The use of cheap technologies and online tools can help or hinder the filmmaker in their quest to tell authentic stories, but the script or narrative and production value must be the best possible so there is a perception of professionalism throughout the production. The community does, in fact, communicate amongst themselves and will certainly 'police' any activity that does not acquiesce within the group. This 'policing' by the community assures transparency, trust, authenticity and protection against spam and unwanted advantages a filmmaker or other community member may seek to squeeze information and/or money out of its community for personal gain. 'The immediacy of new online forms should not be mistaken for a lack of mediation: they are as deliberately constructed as any existing documentary forms, if not more, because of technical constraints...authenticity is highly prized by audiences' (Birchall, 2008, 282-283).

There are certain sacrifices that must be made, which I have undertaken as additional learning curves in engagement in crowd sourcing campaigns, technologies and social media functionalities that are traditionally hired out (i.e. media partners, technology programmers, sales/fulfillment houses, marketing firms). However, these new technologies and online tools have enabled a cheaper, faster delivery of the product and the creation of a uniquely intimate brand; artistically, emotionally; delivered frequently and directly to niche audiences; not through a third party source. Through this practice, I have been able to provide a higher value in the overall creation process and the ongoing development of the relationship amongst the community members. There are many perceived benefits, as well as challenges in this new era of digital technology and social marketing tools that are advantageous for both the filmmaker and their audiences.

Measurable changes in production practices must also be adhered to by utilizing these online tools and cheaper production technology. How does this change the storytelling process? Without a doubt, technological considerations must be made for the lack of financing and of a large crew. The entrepreneurial filmmaker, is now essentially a 'one-(wo)man-band' where every single shot, direction, post-production/editing, writing, producing, marketing and digital online 
development and management can be achieved by the sole artist. Aesthetic compromises are also undeniably at stake. However, it is worth noting that with small cinema, mobile and with online video distribution choices that are growing every day, there are many outlets for distribution that do not require a $35 \mathrm{~mm}$. or HD production aesthetic to tell a story. Ultimately, the script is still at the base of all storytelling measures - it is only the methodology and the system of delivery that has changed. It is much easier in this environment to take advantage of these resources to create multiple projects, thus enhancing the value of the overall brand.

The film business remains a single product industry. The product may be available on many different platforms, but it is still the same thing. For such a capital intensive enterprise to sell only one thing is a squandering of time and money. Films can be a platform to launch many different products and enterprises, some of which can also enhance the experience and build the community (Hope, 2010). With the attraction of crowd funding sites such as, Kickstarter and IndieGogo, financial resources are now available for filmmakers, who don't have access to rich uncles, or mix with the Hollywood investor crowd, or who can fund their projects across a mass of credit cards in order to raise needed funds for their film projects. Expectations have changed considerably, probably completely. Buyers and audiences behaviors are different, that is those that still remain. Products are valued at different levels. We live in a new world. Our strategies must change with it (Hope, 2010). Crowd sourcing and fan-building opportunities are possible through these engaging social media communities, which no longer hold a stigma that it only finances 'amateur art' -although there might be some sprinkled throughout the available projects. The production and fundraising of a film in this style is beginning to produce a more valuable, sustainable, niche-market product and is changing the traditional market structure of distribution and delivery for independent filmmakers outside the Hollywood system. It is also providing a platform for artists in countries without the support of film communities, government subsidies or fundraising activities. This enables a global access to films and stories that might otherwise never be told. 'On the face of it, Kickstarter is pretty harmless, and I think the founder's intentions are good. It's great that people can raise money for cool things from the crowd. It's hard to raise money, especially for the arts, and there have always been a lot of gatekeepers in the way. Now, the people can decide what gets funded' (Newman, 2011).

Still, further questions for scholarly and industry inquest still linger, waiting to be answered. Will it be profitable? How can a filmmaker, who makes a film online for free ever hope to see a profit, much less sustainability? For Hollywood, what affects the bottom-line is the question they [studios] are waiting to see emerge profitable. That's one of the inherent problems I see with the free strategy. The film business is already risky, and this adds on a whole other layer of risk. What if you give the film away and nobody cares? No sales of anything? Then you've shot yourself in the foot - you can't go back and start charging for the film and expect people to attach any sort of value to it (Parks, 2009).

If it is profitable, how will this change the open democracy of the 'wild west' we see now in this new trend? Will it continue to be available to all in a utopian world or be monopolised, packaged and sold as IPO to the highest bidder forcing filmmakers to go through yet another middleman to make their films? Will these online, participatory, transmedia interactions incentivize the audience to buy the finished product and any subsequent ancillary products associated with the creative product? What about future projects the filmmaker produces? Can there be added sustainability to this model? These questions and more that arise through research and practice, will continue to merit further question and research. With arts funding continuing to dwindle, such as the reduction in grants and lottery funding, filmmakers have turned to crowd funding to finance their livelihoods - but will the audiences enable that to become a reality, or will the studio systems in place prevail? 
On a larger scale, projects in this realm will emerge answering the question of how this new methodology of filmmaking relates to a wider economic, cultural, environmental and social scale. As Hope (2011) states, creators, distributors, and marketeers have already accepted a dividing line between art and commerce and as well as between content and marketing. Hence, by not engaging the filmmakers in how to use marketing tools within their narrative and how to bring narrative techniques to marketing, we also diminish the discovery and promotional potential of all films.

Hopefully, through research and continued practice, and the great many other filmmakers who are engaging audiences with participatory filmmaking methods, will be seen at least to make a significant impact in any particular way through new creation practices, through the use of new technologies and delivery channels available outside the traditional distribution and delivery channels. Fortunately, there is evidence to suggest it's a new world order for filmmakers and for audiences.

\section{REFERENCES}

Birchall, D. (2008). Online documentary. Ed. T. Austin, \& W. de Jong. Rethinking Documentary: New Perspectives, New Practices, 279-282. New York: University Press McGraw-Hill Education.

Blagrove, Jr., I. (2008). Rice N. Pease: Alternative, independent and provocative. Ed. T. Austin, \& W. de Jong. Rethinking Documentary: New Perspectives, New Practices. New York: University Press McGraw \& Hill Education.

Hope, T. (2010). 38 Reasons the film industry is failing today, Huffington Post. Retrievedf on 9 May 2010 from http://www.huffingtonpost.com/ted-hope/38-ways-the-filmindustry_b_569260.html

de Jong, W., \& Austin, T. (2008). You want to know that, this is real, this is what happened; An interview with John Smithson. Ed. T. Austin, \& W. de Jong. Rethinking Documentary: New Perspectives, New Practices. New York: University Press McGraw-Hill Education.

Juhasz, A. (2008). Documentary on YouTube: The failure of the direct cinema of slogan. Ed. T. Austin, \& W. de Jong. Rethinking Documentary: New Perspectives, New Practices, 304. New York: University Press McGraw-Hill Education.

Kirsner, S. (2009). Fans, Friends and Followers: Building an audience and a creative career in the digital age. Cinema Tech.

Knudsen, E. (2008). Transcendental realism in documentary. Ed. T. Austin, \& W. de Jong. Rethinking Documentary: New Perspectives, New Practices. New York: University Press McGraw-Hill Education.

Newman, B. (2011). The problem I'm having with kickstarter. Springboard Media. Retrieved on 24 June 2011 from http://springboardmedia.blogspot.com/2011/06/problem-im-having-with-kickstarter.html

Parks, S. (2009). To Free or Not to Free, Independent Film Blog. Retrieved on 6 January 2010 from http://independentfilmblog.com/archives/to-free-or-not-to-free

Rothwell, J. (2008). Filmmakers and their subjects. Ed. T. Austin, \& W. de Jong. Rethinking Documentary: New Perspectives, New Practices. New York: University Press McGraw-Hill Education.

Rouch, J. ([1975] 2003). The camera and the man. Ed. P. Hockings. Principles of visual anthropology. Chicago: Mouton de Gruyter.

Ward, P. (2008). Drama-documentary: The 'flight 93' films. Ed. T. Austin, \& W. de Jong. Rethinking Documentary: New Perspectives, New Practices. New York: University Press McGraw \& Hill Education. 